\title{
Pengaruh Kemampuan Analisis terhadap Prestasi Belajar Matematika Ditinjau dari Intellegent Quotion (IQ)
}

\author{
Agus Setiawan ${ }^{1}$ \\ 1) Institut Agama Islam Ma'arif NU (IAIMNU) Metro Lampung

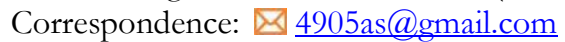

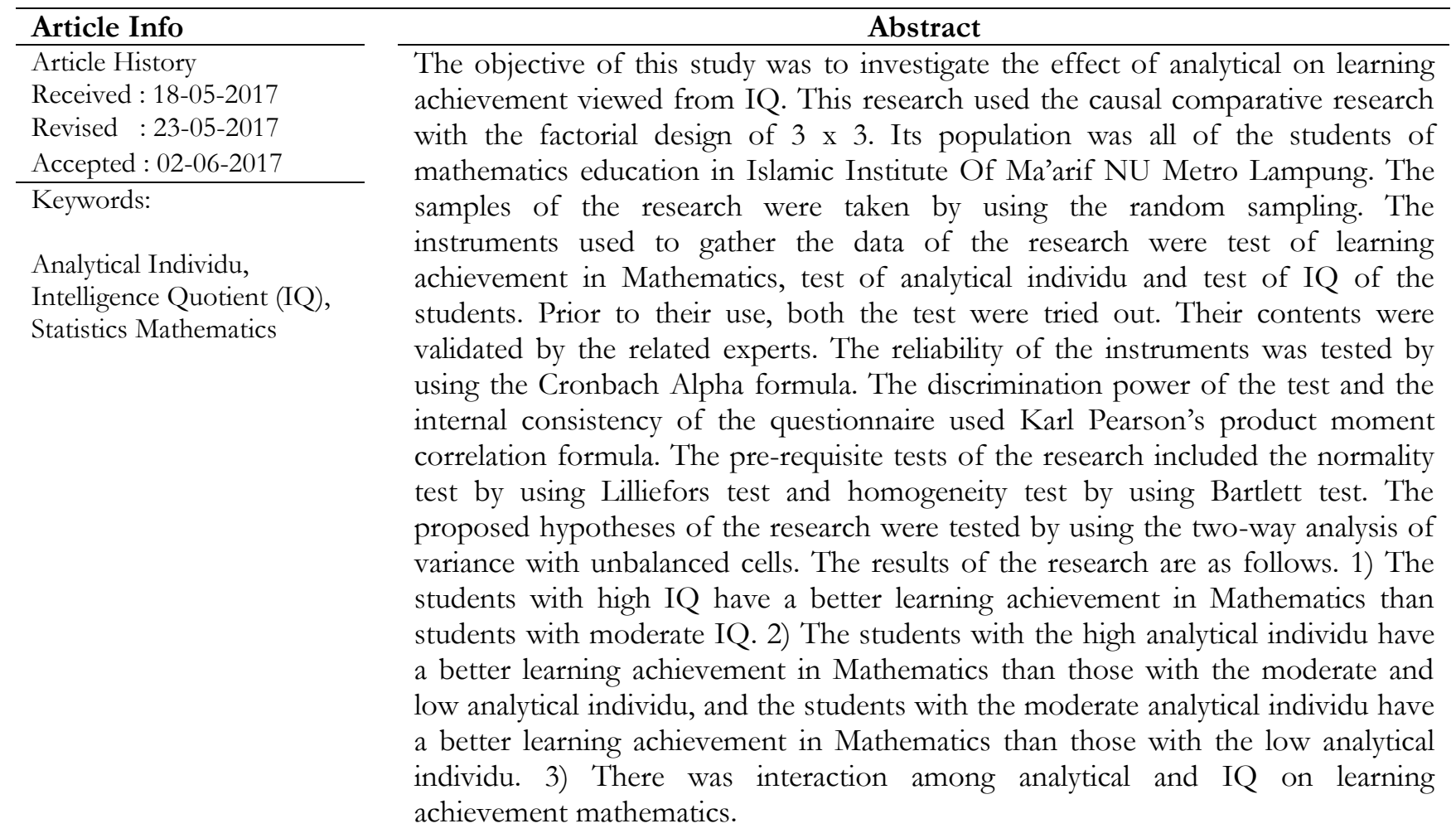

\section{PENDAHULUAN}

Pendidikan merupakan ujung tombak kemajuan bangsa, terutama dalam menghadapi era globalisasi dimana kemajuan teknologi yang pesat menyebabkan perubahan struktur kehidupan dalam masyarakat. Sejalan dengan kemajuan tersebut pendidik dan peserta didik dituntut untuk berperan aktif dalam menjalankan misi pendidikan. Dalam islam menuntut ilmu merupakan suatu kewajiban baik ilmu agama maupun ilmu ilmu pengetahuan umum. Dalam hadist Rasullulloh SAW bersabda:

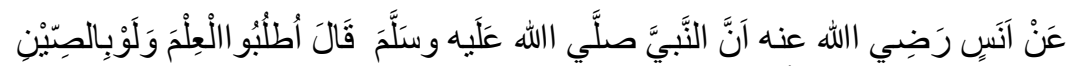

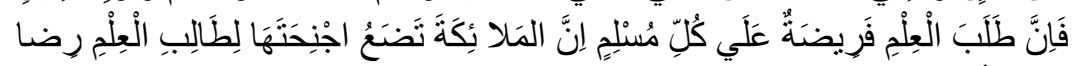

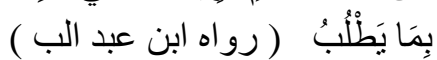

Dari Anas, r.a. bahwa Nabi saw telah bersabda: 
Tuntutlah ilmu meskipun di negeri Cina, karena sesunggubnya menuntut ilmu itu wajib bagi setiap orang Islam. Sungguh malaikat itu meletakekan sayap-sayapnya untuk orang yang menuntut ilmu karena senang terhadap apa yang dicarinya. (H.R. Ibnu Abdil Bar)

Hadits yang diriwayatkan oleh Ibnu Abdil bar tersebut di atas, menjelaskan kepada kita betapa pentingnya menuntut ilmu pengetahuan, sekalipun ke tempat yang jauh dari tempat tinggal kita. Pentingnya menuntut ilmu pengetahuan berdasarkan hadits ini adalah dinyatakan tegas oleh Rasulullah saw dengan menggunakan kata perintah, yaitu: Tuntutlah atau carilah.

Kata perintah tersebut menunjukkan suatu kewajiban Dan kewajiban untuk mencari ilmu pengetahuan ituharus maksimal atau setinggi-tingginya sampai ke negeri Cina. Selain menggunakan kata perintah untuk menuntut ilmu pengetahuan yang menunjukkan suatu kewajiban yang harus dilaksnakan, lebih lanjut Rasulullah Saw menegaskan dalam hadits ini dengan kata-kata:

\section{Artinya : "Karena sesunggubnya menuntut ilmu adalab wajib bagi setiap orang yang beragama Islam."}

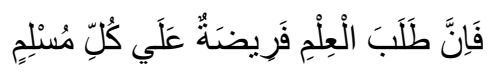

Kemudian Rasulullah saw menggambarkan betapa istimewanya orang-orang menuntut ilmu pengetahuan itu, sehingga malaikat-malaikat Allah suka dan akan selalu rela meskipun jauh dari tempat tinggalnya.

Dalam Hadits lain Rasulullah saw bersabda :

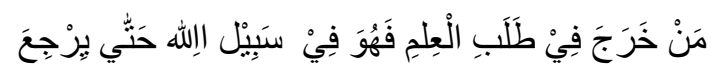

Artinya : "Orang-orangyang keluar dalam mencari ilmu, maka berada di jalan Allah sampai ia kembali (ke rumahnya)." (H.R. Al-Tirmidzi)

Matematika mempunyai peranan yang sangat penting dalam kehidupan sehari-hari. Matematika banyak diperlukan aplikasinya dalam melaksanakan aktivitas di segala bidang kehidupan, baik bidang pendidikan, perdagangan (ekonomi), sosial maupun bidang-bidang yang lain. Matematika mampu mengarahkan manusia untuk berfikir secara logis dan memberikan solusi yang tepat dalam kehidupan sehari-hari. Dengan kemampuan matematika yang baik, akan mendukung seseorang untuk memperoleh berbagai macam bekal dalam menghadapi tantangan dalam era global. Kemampuan berfikir kritis, analisis, logis, cermat, sistematis, kreatif dan inovatif merupakan beberapa kemampuan yang dapat ditumbuhkembangkan melalui pendidikan matematika yang baik. Arti penting dan peranan matematika bagi ilmu-ilmu modern dewasa ini lebih luas dan mendalam lagi.

Hampir semua penemuan ilmiah di dunia ini dibantu dan ditopang oleh matematika. Lebih dari 700 tahun lalu filsuf Inggris Roger Bacon mengatakan "Mathematics is the gate and key of the science" (Matematika merupakan pintu gerbang dari ilmu-ilmu). Sebuah julukan lagi yang diberikan dalam Illustrated Word Encyclopedia menyatakan bahwa mathematics is the "mother of science" because every science has its mathematical side (matematika merupakan "ibu dari ilmu-ilmu" karena setiap ilmu mempunyai sisi matematikanya).

Keberhasilan pembelajaran matematika tidak terlepas dari kemampuan individu yang dimiliki oleh mahasiswa, yaitu faktor internal diantaranya kemampuan analisis mahasiswa. Kemampuan analisis sebagai kemampuan untuk melihat kemungkinan-kemungkinan untuk menyelasaikan suatu masalah dan merupakan bentuk pemikiran yang kurang mendapat perhatian dalam pendidikan formal. Analisis adalah kemampuan untuk mengidentifikasi maksud dan hubungan-hubungan kesimpulan yang benar diantara pernyataan, pertanyaan, konsep, gambaran, atau bentuk lain yang mewakili yang dimaksudkan 
untuk mengungkapkan keyakinan, pendapat, pengalaman, alasan, informasi atau opini. Facione menyatakan bahwa kemampuan analisis berhubungan kuat dengan prestasi kognitif mahasiswa.

Pernyataan tersebut ditegaskan oleh Wenglinsky yang menyatakan bahwa pembelajaran yang mengutamakan kemampuan analisis mampu mendukung tercapainya prestasi belajar. Salah satu faktor yang dimungkinkan juga mempengaruhi hasil belajar adalah tingkat intelegensi (IQ) seseorang. Setiap orang mempunyai tingkat intelegensi yang berbeda-beda. Untuk itu diperlukan suatu pembelajaran yang tepat untuk diterapkan pada semua tingkat intelegensi, sehingga hasil belajar matematika bisa ditingkatkan. Mengingat pentingnya kemampuan berpikir analisis mahasiswa tersebut, maka di perguruan tinggi perlu disusun suatu setrategi pembelajaran yang baik yang dapat meningkatkan kemampuan berpikir analisis mahasiswa.

\section{METODE PENELITIAN}

Penelitian ini merupakan penelitian kausal komparatif yang dirancang dengan desain faktorial 2 $\times$ 3. Populasi dalam penelitian ini adalah seluruh mahasiswa semester IV, VI dan VIII IAIM-NU Metro Lampung dan sampel diambil dengan teknik random sampling. Penelitian dilakukan di Prodi Pendidikan Matematika IAIM-NU Metro Lampung. Sampel penelitian ini berjumlah 35 mahasiswa. Teknik pengumpulan data adalah metode tes. Instrumen penelitian terdiri atas tes IQ, tes kemampuan analisis dan tes prestasi belajar matematika pada mata kuliah Statistik Matematika 1. Untuk instrumen tes prestasi belajar mengacu pada kriteria yaitu validitas isi dan reliabilitas $\left(\mathrm{r}_{11} \geq 0,7\right)$ dari 5 butir soal yang diujicobakan diperoleh 2 butir soal yang digunakan sebagai alat pengambil data prestasi belajar

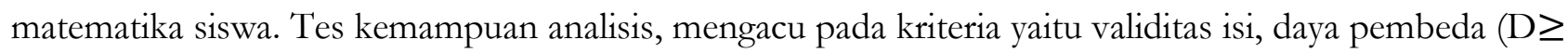
$0,3)$, tingkat kesukaran $(0,3 \leq \mathrm{P} \leq 0,7)$, dan reliabilitas ( $\left.\mathrm{r}_{11} \geq 0,7\right)$, dari 35 butir soal yang diujicobakan diperoleh 25 butir soal yang digunakan sebagai alat pengambil data kemampuan analisis. Uji prasyarat analisis yaitu uji normalitas dengan Lilliefors dan uji homogenitas dengan uji Bartlett. Uji analisis data yang digunakan yaitu analisis variansi dua jalan dengan sel tak sama.

\section{HASIL DAN PEMBAHASAN}

Sebelum data dianalisis menggunakan uji anava dua jalan, terlebih dahulu data harus memenuhi syarat uji normalitas dan uji homogenitas. Dalam penelitian ini uji normalitas menggunakan uji Lilliefors dan uji homogenitas menggunakan uji Bartlett. Dari hasil analisis uji normalitas prestasi belajar matematika tersebut, prestasi belajar matematika pada IQ tinggi dan sedang berasal dari populasi yang berdistribusi normal. Selain itu, untuk prestasi belajar matematika kemampuan Analisis tinggi, sedang, dan rendah juga berasal dari populasi yang berdistribusi normal.

Dari hasil analisis uji homogenitas variansi prestasi belajar matematika, tampak bahwa nilai prestasi belajar matematika untuk IQ tinggi dan sedang berasal dari populasi yang mempunyai variansi sama (homogen). Begitujuga untuk hasil uji homogentas variansi prestasi belajar matematika pada kemampuan analisis tinggi, sedang dan rendah juga berasal dari populasi yang mempunyai variansi sama (homogen).

Hasil perhitungan uji hipotesis dengan analisis variansi dua jalan $2 \times 3$ dengan sel tidak sama dan taraf signifikansi $\alpha=0,05$ disajikan pada Tabel berikut: 
Tabel 1. Rangkuman Analisis Variansi

\begin{tabular}{|c|c|c|c|c|c|c|}
\hline Sumber & JK & $\mathbf{d k}$ & $\mathbf{R K}$ & $\mathbf{F}_{\text {obs }}$ & $\mathbf{F}_{\alpha}$ & $\begin{array}{c}\text { Keputusan } \\
\text { uji }\end{array}$ \\
\hline IQ (A) & 141478,25 & 1 & $\begin{array}{c}141478,2 \\
5\end{array}$ & 1051,65 & 3,25 & $\mathrm{H}_{0 \mathrm{~A}}$ ditolak \\
\hline $\begin{array}{c}\text { Kemampuan } \\
\text { Analisis (B) }\end{array}$ & 4120,92 & 2 & 2060,46 & 15,32 & 3,25 & $\mathrm{H}_{0 \mathrm{~B}}$ ditolak \\
\hline $\begin{array}{c}\text { Interaksi } \\
\text { (AB) }\end{array}$ & 2063,25 & 2 & 1031,63 & 7,67 & 2,36 & $\begin{array}{c}\mathrm{H}_{0 \mathrm{AB}} \\
\text { ditolak }\end{array}$ \\
\hline Galat (G) & 33843,26 & 29 & 134,53 & - & - & - \\
\hline Total & 151563,77 & 34 & - & - & - & - \\
\hline
\end{tabular}

Berdasarkan analisis variansi pada tabel di atas tampak bahwa pada efek utama A (IQ), nilai statistik uji $\mathrm{F}_{\mathrm{a}}=1051,65, \mathrm{~F}_{(0,05,2,35)}=3,25$ dan $\mathrm{DK}=\{\mathrm{F} \mid \mathrm{F}>3,25\}$, ternyata $\mathrm{F}_{\mathrm{a}}>\mathrm{F}_{(0,05,2,35)}$ yang berarti $\mathrm{F}_{\mathrm{a}} \in \mathrm{DK}$ dengan demikian $\mathrm{H}_{0 \mathrm{~A}}$ ditolak. Hal ini berarti pada tingkat signifikansi $\alpha=0,05$ terdapat perbedaan rerata prestasi belajar mahasiswa yang mempunyai IQ tinggi dan sedang. Pada efek utama B (Kemampuan analisis), nilai statistik uji $\mathrm{F}_{\mathrm{b}}=15,32, \mathrm{~F}_{(0,05,2,35)}=3,25$ dan $\mathrm{DK}=\{\mathrm{F} \mid \mathrm{F}>3,25\}$, ternyata $\mathrm{F}_{\mathrm{b}}>\mathrm{F}_{(0,05,2,35)}$ yang berarti $\mathrm{F}_{\mathrm{b}} \in \mathrm{DK}$ dengan demikian $\mathrm{H}_{0 \mathrm{~B}}$ ditolak. Hal ini berarti pada tingkat signifikansi $\alpha=0,05$ terdapat perbedaan rerata prestasi belajar matematika mahasiswa yang memiliki kemampuan analisis tinggi, sedang dan rendah. Pada efek interaksi AB (IQ dan kemampuan analisis), nilai statistik uji $\mathrm{F}_{\mathrm{ab}}=7,67, \mathrm{~F}_{(0,05,4,35)}=2,36$ dan $\mathrm{DK}=\{\mathrm{F} \mid \mathrm{F}>2,36\}$, ternyata $\mathrm{F}_{\mathrm{ab}}<\mathrm{F}_{(0,05,2,135)}$ yang berarti $\mathrm{F}_{\mathrm{ab}} \in \mathrm{DK}$ dengan demikian $\mathrm{H}_{0 \mathrm{AB}}$ ditolak. Hal ini berarti pada tingkat signifikan $\alpha=0,05$ terdapat interaksi antara IQ dan kemampuan analisis.

Berdasarkan hasil analisis variansi dua jalan dengan sel tak sama diperoleh bahwa $\mathrm{H}_{0 \mathrm{~A}}$ dan $\mathrm{H}_{0 \mathrm{~B}}$ ditolak namun $\mathrm{H}_{0 \mathrm{AB}}$ ditolak, sehingga perlu dilakukan uji lanjut antar baris, uji lanjut antar kolom dan uji lanjut antar sel pada baris dan kolom yang sama. Dalam penelitian ini uji lanjut menggunakan uji komparasi ganda dengan metode Scheffe.

Karena hanya terdiri dari dua kelompok maka tidak perlu uji lanjut pasca anava untuk antar baris. Untuk menentukan metode mana yang lebih baik maka cukup melihat rerata marjinalnya.

Berdasarkan hasil analisis variansi dua jalan dengan sel tak sama untuk efek utama faktor A (IQ) diperoleh kesimpulan $\mathrm{H}_{0 \mathrm{~A}}$ ditolak. Karena $\mathrm{H}_{0 \mathrm{~A}}$ ditolak maka perlu dilakukan uji lanjut anava yaitu uji komparasi ganda. Karena hanya terdiri dari dua kelompok maka tidak perlu uji lanjut pasca anava untuk antar baris. Untuk menentukan metode mana yang lebih baik maka cukup melihat rerata marjinalnya. Dari rerata marjinal diketahui rerata untuk IQ tinggi yaitu 68,56 lebih baik daripada rerata IQ sedang yaitu 58,77, sehingga dapat disimpulkan bahwa IQ tinggi mempunyai prestasi belajar yang lebih baik daripada rerata IQ sedang.

Berdasarkan hasil analisis variansi dua jalan dengan sel tak sama untuk efek utama faktor B (tingkat kemampuan analisis) diperoleh kesimpulan $\mathrm{H}_{0 \mathrm{~B}}$ ditolak. Karena $\mathrm{H}_{0 \mathrm{~B}}$ ditolak maka perlu dilakukan uji lanjut anava yaitu uji komparasi ganda. Pada uji komparasi ganda antara kolom 1 dan kolom 2 ada perbedaan rerata prestasi belajar matematika mahasiswa yang memiliki kemampuan analisis tinggi dengan rerata mahasiswa yang memiliki kemampuan analisis sedang. Berdasarkan rerata marjinal menunjukkan bahwa rerata prestasi belajar matematika mahasiswa yang memiliki kemampuan analisis tinggi sebesar 73,55 sedangkan rerata prestasi belajar mahasiswa yang memiliki kemampuan analisis sedang sebesar 63,45 . Hal ini menunjukkan bahwa rerata prestasi belajar matematika mahasiswa yang memiliki kemampuan analisis tinggi lebih baik dari rerata prestasi belajar mahasiswa yang memiliki 
kemampuan analisis sedang. Pada uji komparasi ganda antara kolom 1 dan kolom 3 ada perbedaan rerata prestasi belajar matematika mahasiswa yang memiliki kemampuan analisis tinggi dengan rerata mahasiswa yang memiliki kemampuan analisis rendah. Berdasarkan rerata marjinal menunjukkan bahwa rerata prestasi belajar matematika mahasiswa yang memiliki kreativitas belajar matematika tinggi 75,33 sedangkan rerata prestasi belajar mahasiswa yang memiliki kreativitas belajar matematika rendah sebesar 56,63. Hal ini menunjukkan bahwa rerata prestasi belajar matematika mahasiswa yang memiliki kemampuan analisis tinggi lebih baik dari rerata prestasi belajar mahasiswa yang memiliki kemampuan analisis rendah. Pada uji komparasi ganda antara kolom 2 dan kolom 3 tidak ada perbedaan rerata prestasi belajar matematika mahasiswa yang memiliki kemampuan analisis sedang dengan rerata mahasiswa yang memiliki kemampuan analisis rendah. Hal ini menunjukkan bahwa rerata prestasi belajar matematika mahasiswa yang memiliki kemampuan analisis sedang sama baik dari rerata prestasi belajar mahasiswa yang memiliki kemampuan analisis rendah.

Berdasarkan penjelasan tersebut, dapat disimpulkan bahwa prestasi belajar mahasiswa yang memiliki kemampuan analisis tinggi lebih baik daripada mahasiswa yang memiliki kemampuan analisis sedang dan rendah. Sedangkan prestasi belajar matematika mahasiswa yang memiliki kemampuan analisis sedang sama baik dengan mahasiswa yang memiliki kemampuan analisis rendah.

Berdasarkan hasil uji anava dua jalan dengan sel tak sama diperoleh bahwa $\mathrm{H}_{0 \mathrm{AB}}$ ditolak. Karena

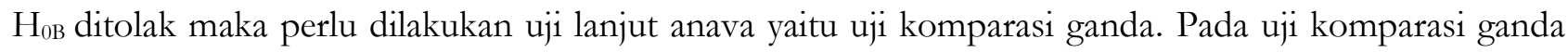
antara sel 1 dan 2 ada perbedaan prestasi belajar matematika antara mahasiswa yang mempunyai IQ tinggi yang memiliki kemampuan analisis tinggi dan mahasiswa yang mahasiswa yang mempunyai IQ tinggi yang memiliki kemampuan analisis sedang. Berdasarkan rerata marjinal menunjukkan bahwa rerata prestasi belajar matematika mahasiswa yang mempunyai IQ tinggi yang memiliki kemampuan analisis tinggi yaitu 78,40 sedangkan rerata prestasi belajar mahasiswa yang mempunyai IQ tinggi yang memiliki kemampuan analisis sedang sebesar 65,85. Hal ini menunjukkan bahwa pada IQ tinggi rerata prestasi belajar matematika mahasiswa yang memiliki kemampuan analisis tinggi lebih baik dari pada rerata prestasi belajar mahasiswa yang memiliki kemampuan analisis sedang.

Pada uji komparasi ganda antara sel 1 dan 3 ada perbedaan prestasi belajar matematika antara mahasiswa yang mempunyai IQ tinggi yang memiliki kemampuan analisis tinggi dan mahasiswa yang mahasiswa yang mempunyai IQ tinggi yang memiliki kemampuan analisis sedang. Berdasarkan rerata marjinal menunjukkan bahwa rerata prestasi belajar matematika mahasiswa yang mempunyai IQ tinggi yang memiliki kemampuan analisis tinggi yaitu 78,40 sedangkan rerata prestasi belajar mahasiswa yang mempunyai IQ tinggi yang memiliki kemampuan analisis rendah sebesar 59,67. Hal ini menunjukkan bahwa pada IQ tinggi rerata prestasi belajar matematika mahasiswa yang memiliki kemampuan analisis tinggi lebih baik dari pada rerata prestasi belajar mahasiswa yang memiliki kemampuan analisis rendah.

Pada uji komparasi ganda antara sel 2 dan 3 tidak ada perbedaan prestasi belajar matematika antara mahasiswa yang mempunyai IQ tinggi yang memiliki kemampuan analisis tinggi dan mahasiswa yang mahasiswa yang mempunyai IQ tinggi yang memiliki kemampuan analisis sedang. Hal ini menunjukkan bahwa pada IQ tinggi rerata prestasi belajar matematika mahasiswa yang memiliki kemampuan analisis sedang sama baik dengan rerata prestasi belajar mahasiswa yang memiliki kemampuan analisis rendah. Pada uji komparasi ganda antara sel 2.1 dan sel 2.2 pada baris kedua diketahui ada perbedaan prestasi belajar matematika antara mahasiswa yang mempunyai IQ sedang yang memiliki kemampuan analisis tinggi dan mahasiswa yang mahasiswa yang mempunyai IQ sedang yang memiliki kemampuan analisis sedang. Berdasarkan rerata marjinal menunjukkan bahwa rerata 
prestasi belajar matematika mahasiswa yang mempunyai IQ sedang yang memiliki kemampuan analisis tinggi yaitu 69,09 sedangkan rerata prestasi belajar mahasiswa yang mempunyai IQ sedang yang memiliki kemampuan analisis sedang sebesar 56,31. Hal ini menunjukkan bahwa pada IQ sedang rerata prestasi belajar matematika mahasiswa yang memiliki kemampuan analisis tinggi lebih baik dari pada rerata prestasi belajar mahasiswa yang memiliki kemampuan analisis sedang.

Pada uji komparasi ganda antara sel 2.1 dan 2.3 pada baris kedua diperoleh ada perbedaan prestasi belajar matematika antara mahasiswa yang mempunyai IQ sedang yang memiliki kemampuan analisis tinggi dan mahasiswa yang mahasiswa yang mempunyai IQ sedang yang memiliki kemampuan analisis rendah. Berdasarkan rerata marjinal menunjukkan bahwa rerata prestasi belajar matematika mahasiswa yang mempunyai IQ sedang yang memiliki kemampuan analisis tinggi yaitu 69,09 sedangkan rerata prestasi belajar mahasiswa yang mempunyai IQ sedang yang memiliki kemampuan analisis rendah sebesar 50,91. Hal ini menunjukkan bahwa pada IQ sedang rerata prestasi belajar matematika mahasiswa yang memiliki kemampuan analisis tinggi lebih baik dari pada rerata prestasi belajar mahasiswa yang memiliki kemampuan analisis rendah. Pada uji komparasi ganda antara sel 2.2 dan 2.3 pada baris kedua diperoleh tidak ada perbedaan prestasi belajar matematika antara mahasiswa yang mempunyai IQ sedang yang memiliki kemampuan analisis sedang dan mahasiswa yang mahasiswa yang mempunyai IQ tinggi yang memiliki kemampuan analisis rendah. Hal ini menunjukkan bahwa pada IQ sedang rerata prestasi belajar matematika mahasiswa yang memiliki kemampuan analisis sedang sama baik dengan rerata prestasi belajar mahasiswa yang memiliki kemampuan analisis rendah. Dari penjelasan di atas dapat disimpulkan bahwa:

Pada kategori mahasiswa dengan IQ tinggi. Mahasiswa yang mempunyai kemampuan analisis tinggi memberikan prestasi belajar lebih baik daripada mahasiswa yang mempunyai kemampuan analisis sedang dan rendah. Sedangkan mahasiswa yang mempunyai kemampuan analisis sedang memberikan prestasi belajar sama baik dengan mahasiswa yang mempunyai kemampuan analisis rendah. Pada kategori mahasiswa dengan IQ sedang. Mahasiswa yang mempunyai kemampuan analisis tinggi memberikan prestasi belajar lebih baik daripada mahasiswa yang mempunyai kemampuan analisis sedang dan rendah. Sedangkan mahasiswa yang mempunyai kemampuan analisis sedang memberikan prestasi belajar sama baik dengan mahasiswa yang mempunyai kemampuan analisis rendah.

Berdasarkan hasil uji anava dua jalan dengan sel tak sama diperoleh bahwa $\mathrm{H}_{0 \mathrm{AB}}$ ditolak. Karena

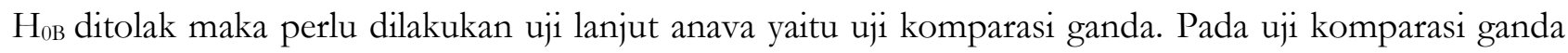
antara sel 1.1 dan 2.1 pada kolom pertama pada kemampuan analisis tinggi, ada perbedaan rerata antara mahasiswa yang mempunyai IQ tinggi dan sedang. Berdasarkan rerata menunjukkan bahwa rerata prestasi belajar matematika mahasiswa yang memiliki kemampuan analisis tinggi dan IQ tinggi sebesar 78,40 sedangkan rerata prestasi belajar mahasiswa yang memiliki kemampuan analisis tinggi dan IQ sedang sebesar 69,09. Hal ini menunjukkan bahwa rerata mahasiswa yang memiliki kemampuan analisis tinggi dan IQ tinggi lebih baik daripada mahasiswa yang memiliki kemampuan analisis tinggi dan IQ sedang. Pada uji komparasi ganda antara sel 1.2 dan 2.2 pada kolom pertama pada kemampuan analisis sedang, ada perbedaan rerata antara mahasiswa yang mempunyai IQ tinggi dan sedang. Berdasarkan rerata marjinal menunjukkan bahwa rerata prestasi belajar matematika mahasiswa yang memiliki kemampuan analisis sedang dan IQ tinggi sebesar 65,85 sedangkan rerata prestasi belajar mahasiswa yang memiliki kemampuan analisis tinggi dan IQ sedang sebesar 56,31. Hal ini menunjukkan bahwa rerata mahasiswa yang memiliki kemampuan analisis sedang dan IQ tinggi lebih baik daripada mahasiswa yang memiliki kemampuan analisis tinggi dan IQ sedang. Pada uji komparasi ganda antara 
sel 1.3 dan sel 3.3 pada kolom ketiga pada kemampuan analisis rendah, tidak ada perbedaan rerata antara mahasiswa yang mempunyai IQ tinggi dan sedang. Hal ini menunjukkan bahwa rerata mahasiswa yang memiliki kemampuan analisis rendah dan IQ tinggi lebih baik daripada mahasiswa yang memiliki kemampuan analisis tinggi dan IQ sedang.

Berdasarkan penjelasan tersebut, dapat disimpulkan bahwa pada kategori mahasiswa dengan kemampuan analisis tinggi. Mahasiswa dengan IQ tinggi mempunyai prestasi belajar yang lebih baik daripada mahasiswa yang mempunyai IQ sedang. Pada kategori mahasiswa dengan kemampuan analisis sedang. Mahasiswa dengan IQ tinggi mempunyai prestasi belajar yang lebih baik daripada mahasiswa yang mempunyai IQ sedang. Pada kategori mahasiswa dengan kemampuan analisis rendah. Mahasiswa dengan IQ tinggi mempunyai prestasi belajar sama baik dengan mahasiswa yang mempunyai IQ sedang.

Berdasarkan penjelasan analisis hipotesis keempat diatas, dapat kita ketahui bahwa hipotesis keempat dalam penelitian ini tidak semuanya sesuai dengan hasil penelitian, yaitu:

Pada kategori mahasiswa dengan kemampuan analisis tinggi. Mahasiswa dengan IQ tinggi mempunyai prestasi belajar yang lebih baik daripada mahasiswa yang mempunyai IQ sedang. Pada kategori mahasiswa dengan kemampuan analisis sedang. Mahasiswa dengan IQ tinggi mempunyai prestasi belajar yang lebih baik daripada mahasiswa yang mempunyai IQ sedang. Pada kategori mahasiswa dengan kemampuan analisis rendah. Mahasiswa dengan IQ tinggi mempunyai prestasi belajar yang lebih baik daripada mahasiswa yang mempunyai IQ sedang.

Tidak terpenuhinya hipotesis tersebut dikarenakan peneliti tidak sepenuhnya dapat mengontrol kondisi siswa baik dari segi fisik maupun minat belajar siswa saat mengikuti tes dan mengikuti pembelajaran dikelas. Atau dikarenakan keterbatasan peneliti dalam mengkaji teori dalam kerangka penyusunan kerangka pikir sehingga menghasilkan hipotesis yang tidak sesuai.

\section{SIMPULAN DAN SARAN}

Berdasarkan hasil analisis data dan pembahasan serta mengacu pada rumusan masalah yang telah diuraikan pada bab sebelumnya, maka dapat ditarik kesimpulan bahwa prestasi belajar mahasiswa yang memiliki IQ tinggi mempunyai prestasi belajar yang lebih baik daripada rerata IQ sedang. Prestasi belajar mahasiswa yang memiliki kemampuan analisis tinggi lebih baik daripada mahasiswa yang memiliki kemampuan analisis sedang dan rendah. Sedangkan prestasi belajar matematika mahasiswa yang memiliki kemampuan analisis sedang sama baik dengan mahasiswa yang memiliki kemampuan analisis rendah. Pada kategori mahasiswa dengan IQ tinggi. Mahasiswa yang mempunyai kemampuan analisis tinggi memberikan prestasi belajar lebih baik daripada mahasiswa yang mempunyai kemampuan analisis sedang dan rendah. Sedangkan mahasiswa yang mempunyai kemampuan analisis sedang memberikan prestasi belajar sama baik dengan mahasiswa yang mempunyai kemampuan analisis rendah. Pada kategori mahasiswa dengan IQ sedang. Mahasiswa yang mempunyai kemampuan analisis tinggi memberikan prestasi belajar lebih baik daripada mahasiswa yang mempunyai kemampuan analisis sedang dan rendah. Sedangkan mahasiswa yang mempunyai kemampuan analisis sedang memberikan prestasi belajar sama baik dengan mahasiswa yang mempunyai kemampuan analisis rendah. Pada kategori mahasiswa dengan kemampuan analisis tinggi. Mahasiswa dengan IQ tinggi mempunyai prestasi belajar yang lebih baik daripada mahasiswa yang mempunyai IQ sedang. Pada kategori mahasiswa dengan kemampuan analisis sedang. Mahasiswa dengan IQ tinggi mempunyai prestasi belajar yang lebih baik daripada mahasiswa yang mempunyai IQ sedang. Pada kategori mahasiswa 
dengan kemampuan analisis rendah. Mahasiswa dengan IQ tinggi mempunyai prestasi belajar sama baik dengan mahasiswa yang mempunyai IQ sedang.

Dalam penelitian ini memberikan suatu pemikiran yang berhubungan dengan peningkatan prestasi belajar matematika disarankan dalam melaksanakan kegiatan pembelajaran matematika, sebaiknya guru memperhatikan IQ mahasiswa sehingga proses belajar dapat diikuti oleh semua mahasiswa, tidak terlalu cepat dan juga tidak terlalu lambar dalam memberikan penjelasan. Dalam kegiatan assesment seperti UTS dan UAS, dosen diharapkan membuat soal minimal pada tingkatan analisis bukan pada ingatan maupun pengetahuan agar dapat meningkatkan kemampuan analisis mahasiswa. Penulis berharap agar para peneliti atau calon peneliti dapat meneruskan atau mengembangkan penelitian ini untuk variabel-variabel yang lain untuk meningkatkan prestasi belajar matematika mahasiswa. Hasil penelitian ini terbatas pada materi statistik. Untuk itu dapat dikembangkan pada materi lain dan jenjang yang lain pula.

\section{DAFTAR PUSTAKA}

Allen, J .2004. "How Do Critical Thinking Skils Enhace Student Achievement”.jurnal online.www.eyeoneeducation.com.

Baharuddin. 2008. Teori Belajar dan Pembelajaran. Jakarta: Ar-Ruzz Media.

Budiyono. 2003. Metodologi Penelitian Pendidikan. Surakarta: UNS Press.

Budiyono. 2009. Statistika Untuk Penelitian. Surakarta: UNS Press.

Budiyono . 2011. Penilaian Hasil Belajar. Surakarta: UNS Press.

Erman Suherman, dkk, Strategi Pembelajaran Matematika Kontemporer. Bandung: JICA

Idri Shaffat. 2009. Optimized Learning Strategis. Jakarta : Prestasi Pustaka

Mulyono Abdurrahman. 2003. Pendidikan Bagi Anak Berkesulitan Belajar. Jakarta: Rineka Cipta.

Ngalim Purwanto. 2007. Psikologi Pendidikan. Bandung: Remaja Rosdakarya.

Oemar Hamalik. 2007. Kurikulum dan Pembelajaran. Jakarta: Bumi Aksara.

Peter A. Facione. Critical Thinking: What It Is and Why It Counts. Insight Assesment

Ruseffendi. 1991. Pengantar Kepada Pembantu Guru Mengembangkan Kompetensinya dalam Pengajaran Matematika untuk Meningkatkan CBSA. Bandung : Tarsito.

Saifuddin Azwar. 1999. Pengantar Psikologi Intelegensi. Yogyakarta:Pustaka Pelajar.

Slameto. 2003. Belajar dan Faktor-faktor yang Mempengarubinya. Jakarta : Rineka Cipta.

Slavin, R.E. 2008. Cooperatif Learning. Bandung: Nusa Media.

Soejadi. 2000. Kiat Pendidikan Matematika Di Indonesia. Jakarta: Dirjen Perdosenan Tinggi dan Depdikbud

Suherman. 2003. Strategi Pembelajaran Matematika Kontemporer. Bandung: Universitas Pendidikan Indonesia.

Sugiyono. 2009. Metode Penelitian Pendidika Pendekatan Kuantitatif, Kualitatif, dan R\&D .Bandung: Alfabeta. 
Numerical: Jurnal Matematika dan Pendidikan Matematika, Vol. 1 No. 1 Juni 2017, 25-34

Agus Setiawan

Suharsinmi Arikunto. 2009. Dasar-Dasar Evaluasi Pendidikan.Jakarta: Bummi Aksara

The Liang Gie. 1999. Filsafat Matematika. Yogyakarta : Pusat Ilmu Berguna.

William Bernard \& Jules Leopold. 2000. Test Analisa IQ \& Kepribadian Anda, Bandung; PionirJaya. 
Numerical: Jurnal Matematika dan Pendidikan Matematika, Vol. 1 No. 1 Juni 2017, 25-34 Agus Setiawan

[Halaman ini sengaja dikosongkan] 